\title{
Eksistensi Kesenian Rebana Gending Desa Langko Dalam Masa Pandemik Covid-19 Di Lombok
}

\author{
I Gede Yudarta ${ }^{1}$, Tri Haryanto \\ Program Studi Seni Program Doktor, \\ Program Pascasarjana Institut Seni Indonesia Denpasar \\ Jalan Nusa Indah, Denpasar, 80235, Indonesia \\ 'gedeyudarta@isi-dps.ac.id
}

Tulisan bertujuan untuk mengungkap eksistensi kesenian Rebana Gending yang merupakan salah satu bentuk musik tradisional Sasak, Lombok. Merebaknya pandemic Corona Virus Disease (Covid) 19 pada tahun 2019 dan mengalami perkembangan di Indonesia pada awal tahun 2020, sangat berdampak dalam berbagai aspek kehidupan termasuk salah satunya di bidang budaya. Kesenian sebagai salah satu aspek kebudayaan mengalami stagnasi dimana banyak aktivitas berkesenian dibekukan sehingga berdampak secara negatif terhadap eksistensi berbagai bentuk kesenian yang terdapat di masyarakat. Fenomena ini juga terjadi pada eksistensi kesenian Rebana Gending yang terdapat di Desa Langko, Kecamatan Lingsar, Kabupaten Lombok Barat, Nusa Tenggara Barat. Rabana Gending merupakan salah satu bentuk kesenian tradisional yang hidup dan berkembang di dalam masyarakat Sasak. Kesenian ini memiliki berbagai keunikan dalam bentuk, fungsi dan musikalitas sehingga berbeda dengan kesenian rebana yang secara umum berkembang di berbagai wilayah di Indonesia. Berkenaan dengan berbagai keunikan tersebut, topik yang dikaji secara khusus akan membahas bentuk dan fungsi kesenian Rebana Gending di dalam kehidupan masyarakat di Lombok. Adapun metode yang digunakan adalah metode kualitatif dengan pendekatan organologi dan ethnomusikologi. Dari pembahasan topik ini selanjutkan akan diketahui dan dipahami bentuk dan fungsi kesenian Rebana Gending di dalam kehidupan masyarakat Sasak.

Kata kunci: eksistensi, rebana gending, musik sasak, covid-19

\section{The Existence of rebana Gending Langko Village During The Covid 19 In Lombok}

The article aims to reveal the existence of Rebana Gending art which is one form of traditional Sasak music, Lombok. Since the outbreak of the Corona Virus Disease (Covid) 19 pandemic in 2019 and it develop in Indonesia in early 2020. This has a great impact on various aspects of life, including culture field. Art as one of the cultural aspects has stagnated in which many art activities are frozen with the result that it became a negative impacts for the existence of various forms of art found in society. This phenomenon also occurs in the existence of Rebana Gending art found in Langko Village, Lingsar District, West Lombok Regency, West Nusa Tenggara. Rabana Gending is a form of traditional art that lives and develops in the Sasak community. This art has a various uniqueness in form, function and musicality resulting that the different from tambourine art which generally develops in various regions in Indonesia. With regard to these various uniqueness, the topic in this study specifically discussing the form and function Rebana Gending in the community life in Lombok. The method used is a qualitative method with an organology and ethnomusicology approach. From the discussion of this topic, furthermore it will to be known and understood the form and function of Rebana Gending art in the lives of Sasak people.

Keywords: existence, rebana gending, sasak music, covid-19

Proses Review : 1 - 20 Mei 2021, Dinyatakan Lolos: 31 Mei 2021 


\section{PENDAHULUAN}

Corona Virus Disease 19 (Covid-19) yang berkembang secara meluas serta menimbulkan korban jiwa pada awal tahun 2020 di Indonesia menyebabkan terjadinya perubahan yang sangat besar dalam berbagai aspek kehidupan, tatanan sosial dan budaya masyarakat. Penyebarannya menimbulkan rasa takut dan kecemasan yang berkelanjutan sehingga terjadi pembatasan dalam berbagai kegiatan di masyarakat. Berbagai media cetak dan elektronik memberitakan pandemic Covid-19 ini sebagai virus yang sangat mematikan dan sudah memakan korban hingga jutaan manusia di seluruh dunia. Di Indonesia khususnya, penyebaran virus ini telah melingkupi berbagai wilayah dan menimbulkan ratusan ribu kasus (262.022 per 24 September 2020) suspect serta menyebabkan puluhan ribu korban jiwa (10.105 per 24 September 2020). Banyaknya korban yang ditimbulkan memaksa pemerintah Indonesia menetapkan musibah ini sebagai bencana Nasional. Pemerintah telah mengeluarkan berbagai kebijakan untuk mengatasi musibah tersebut dari situasi abnormal hingga new-normal serta memberlakukan pembatasan berbagai aktivitas masyarakat dengan aturan social distancing dan physical distancing, dan berbagai aturan lainnya untuk menghindari kerumunan yang ditenggarai sebagai pemicu penyebaran virus tersebut.

Di Lombok penyebaran virus ini terjadi di awal bulan Maret tahun 2020 dan hingga saat ini sudah menimbulkan korban yang cukup banyak. Data terakhir menyebutkan bahwa di wilayah Lombok terkonfirmasi 3.200, meninggal 190, dan yang sembuh 2.497 (https://www.kompas.com/covid-19 diunduh 24 September 2020). Angka ini menunjukkan bahwa wilayah Lombok merupakan salah satu wilayah yang tergolong tinggi berkenaan dengan penyebaran virus ini. Kota Mataram dan beberapa wilayah di Lombok masih berstatus Zona Merah, sehingga pemerintah NTB melaksanakan aturan secara ketat dan membatasi hingga meniadakan berbagai aktivitas yang melibatkan banyak orang.

Kebijakan pemerintah untuk menanggulangi musibah ini menimbulkan dampak yang luar biasa dan menyebabkan terjadi perubahan secara besar-besaran terhadap berbagai tatanan hidup dan aktivitas masyarakat. Salah satu perubahan tersebut sangat dirasakan di dalam tatanan kebudayaan dimana berbagai aktivitas budaya sampai dibekukan karena dikhawatirkan akan menjadi pemicu penyebaran dari virus tersebut. Beberapa aktivitas dan event budaya dari yang berskala internasional, nasional dan lokal dibatalkan penyelenggaraannya demi mencegah terjadinya penyebarluasan virus ini dan mencegah timbulnya korban yang semakin banyak.

Pembatasan dan peniadaan berbagai event serta aktivitas budaya yang dilakukan pada periode bulan Maret hingga Juli sangat berpengaruh terhadap eksistensi seni tradisonal. Berbagai kesenian yang pada awalnya sangat eksis dan memiliki kegiatan yang sangat padat menjadi kehilangan kegiatan dan tidak dapat melaksanakan kegiatan sebagaimana yang telah dilaksanakan pada waktu sebelumnya. Aktivitasnya menjadi menurun ketika kesenian tersebut tidak dilibatkan di dalam kegiatan adat dan budaya. Demikian juga di bidang pariwisata, ketika dunia kepariwisataan di Lombok mulai bangkit lagi dari bencana gempa bumi yang terjadi pada tahun 2018, akhirnya terpuruk lagi setelah semua lokasi dan destinasi wisata di Lombok ditutup. Kesenian-kesenian yang biasanya mengisi atraksi budaya di beberapa hotel dan tempat wisata tidak lagi mendapatkan pekerjaan.

Menurunnya aktivitas budaya dan terhentinya kegiatan berkesenian dialami oleh sekehe Rebana Gending dari Desa Langko yang biasanya mengisi acara di beberapa hotel di kawasan Senggigi dan mengisi kegiatan adat istiadat di masyarakat. Amaq Saturi ketua sekehe Rebana Gending "Buana Putra" Desa Langko mengatakan, saat ini aktivitas berkesenian di kalangan seniman Sasak kondisinya sangat memprihatinkan. Sekehe kesenian yang dipimpinnya tidak ada lagi yang menanggap sejak ditutupnya berbagai aktivitas seni dan pariwisata di Lombok. Jika dalam kondisi normal, sebelum wabah Covid-19 merebak dalam sebulan ada saja yang menanggap untuk mengisi acara adat atau acara atraksi budaya di hotel.

Kesenian Rebana Gending yang terdapat di Desa Langko merupakan salah satu bentuk seni musik tradisional Sasak yang muncul dari hasil kreativitas para seniman Sasak di bidang musik tradisional. Kesenian ini memiliki keunikan dan karakteristik sebagai musik tradisional yang beridentitas Sasak serta hidup dan berkembang di kalangan masyarakat Sasak. Berbeda dengan kesenian rebana pada umumnya yang bernafaskan religius atau sarat dengan nilai-nilai keagamaan, kesenian Rebana Gending justru lebih dekat dengan nilai-nilai tradisi dan budaya Sasak.

Secara umum musik dalam kehidupan masyarakat Sasak dapat dikatagorikan atas tiga katagori yaitu 1) musik tradisional yang muncul dari tradisi budaya dan adat istiadat masyarakat Sasak, 2) musik tradisional yang muncul dari tradisi keagamaan serta 3) musik baru yang merupakan pengembangan dari musik tradisi yang sudah bercampur dengan peralatan musik modern (Yudarta, 2015:369). Kesenian yang menggunakan rebana sebagai instrumen utama sangat beragam jenisnya. Ada kesenian Rebana Gending yang lahir dari tradisi budaya Sasak, sedangkan kesenian rebana yang lain seperti Marawis, Qasidah, Rebana Lima, Hadrah, Rudat adalah kesenian rebana yang muncul dari tradisi keagamaan (islam).

Rebana Gending merupakan satu salah satu kesenian yang dilatarbelakangi tradisi budaya Sasak dari berbagai jenis rebana yang terdapat di Lombok. Hal ini menunjukkan bahwa kesenian Rebana Gending menjadi kesenian 
yang langka dan unik karena hanya terdapat di wilayah Pulau Lombok. Dari keunikan tersebut di dalam peper ini secara khusus akan dikaji permasalahan eksistensi kesenian tersebut pada masa pandemic covid-19. Berkenaan dengan itu terdapat dua hal yaitu bentuk dan fungsinya dalam kehidupan masyarakat Sasak. Tujuannya adalah agar masyarakat luas dapat mengetahui dan memahami eksistensi kesenian Rebana Gending terutama berkaitan dengan bentuk dan fungsinya serta bagaimana keberadaannya pada masa pandemic covid-19 di dalam kehidupan masyarakat Sasak.

\section{METODE DAN PENDEKATAN}

Penulisan peper ini menggunakan metode kualitatif dimana analisis berbagai ulasan dan analisis yang terdapat di dalamnya merupakan hasil pengolahan data yang diperoleh melalui observasi, wawancara, studi pustaka dan studi dokumentasi. Hasil analisis tersebut selanjutkan disajikan secara deskriptif dalam bentuk narasi sesuai dengan kaidah penulisan ilmiah. Untuk pembahasan eksistensi, bentuk dan fungsi kesenian Rebana Gending digunakan dua pendekatan yaitu pendekatan organologis untuk mencermati bentuk instrumen dan pendekatan etnomusikologis untuk membedah fungsinya dalam kehidupan masyarakat Sasak.

\section{HASIL DAN PEMBAHASAN}

Membicarakan persoalan eksistensi kesenian Rebana Gending, erat kaitannya dengan keberadaan serta fungsinya di dalam kehidupan masyarakat. Dari berbagai Kamus Bahasa Indonesia disebutkan bahwa eksistensi berarti: adanya, keberadaan, kehidupan. Keberadaan dalam konteks ini adalah kehadiran yang mengandung unsur bertahan atau kemampuan untuk selalu hidup. Ulasan yang berkenaan dengan eksistensi kesenian Rebana Gending adalah menyangkut keberadaan, kehadiran dan kemampuannya bertahan di dalam kehidupan masyarakat. Kesenian Rebana Gending sudah ada di dalam kehidupan masyarakat di Desa Langko dalam kurun waktu yang cukup lama. Sebelum Amaq Saturi mendirikan sekaa ini pada tahun 1987, di Desa Langko sudah ada kesenian Hadrah yang juga merupakan salah satu kesenian islamis yang menggunakan rebana sebagai instrumen pokok. Menurut Amaq Saturi kesenian hadrah tersebut didirikan oleh pamannya yang bernama Amaq Saneli. Sepeninggal Amaq Saneli kesenian ini tidak ada penerusnya sehingga lama-kelamaan tidak berkembang lagi. Di awal tahun 1982 datang Haji Marzuki berasal dari daerah Abian Tubuh, Mataram dan akhirnya menetap di Desa Langko membuat barungan Rebana Gending. Beliau adalah seorang seniman rebana yang sangat handal dan mampu membina beberapa orang seniman di Desa Langko. Namun demikian, setelah bergelar Haji, beliau tidak lagi bisa aktif dan keberadaan kesenian ini selanjutnya diteruskan oleh Amaq Saturi. Untuk lebih memantapkan keberadaan kesenian ini pada

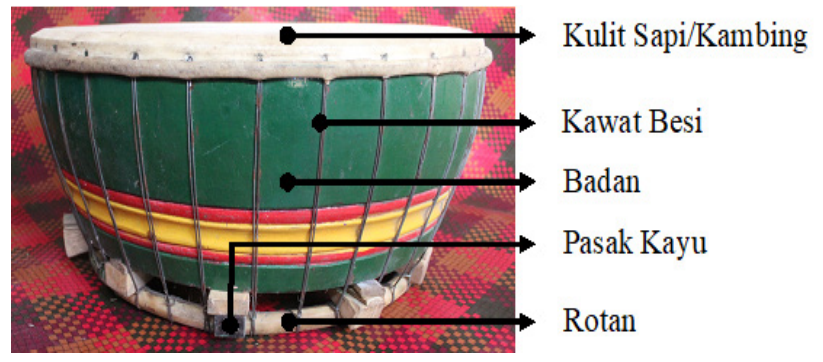

Gambar 1. Bentuk instrumen dan elemen-elemen instrumen Rebana Gending

(Dokumen: I Gede Yudarta, 2020)

tahun 1987 Amaq Saturi mendirikan dan mendeklarasikan sekaa rebana ini dengan nama Buana Putra.

Saat ini keberadaan kesenian Rebana Gending di Desa Langko, Kecamatan Lingsar sudah lebih dari 30 tahun. Sekehe Rebana Gending Buana Putra merupakan salah satu sekehe yang cukup dikenal di kalangan masyarakat luas khususnya di kalangan seniman di Lombok. Sekehe ini sering diundang untuk mengisi kegiatan sosial kemasyarakatan seperti mengisi acara-acara adat seperti nyongkolan, khitanan dan berbagai kegiatan lainnya. Sekehe ini juga sering didaulat oleh pemerintah untuk mengisi program-program yang dilaksanakan oleh pemerintah seperti mengisi kegiatan di Taman Budaya, dan berbagai event budaya yang dilaksanakan oleh pemerintah Kabupaten Lombok Barat dan pemerintah NTB. Selain mengisi kegiatan masyarakat dan pemerintah, sekehe Rebana Gending Buana Putra juga sering ditanggap untuk mengisi acara pertunjukan di beberapa hotel yang terdapat di wilayah Mataram, beberapa hotel yang terdapat di wilayah Senggigi.

Mengamati aspek historis dan berbagai aktivitas yang telah dilakukan hal ini menunjukkan bahwa eksistensi sekehe Rabana Gending Buana Putra masih kuat di dalam kehidupan masyarakat. Ketika banyak kelompok kesenian tradisional yang berguguran hingga mengalami kepunahan, sekehe ini masih menunjukkan eksistensinya dan mampu berperan secara positif dalam berbagai aspek kehidupan masyarakat.

\section{Bentuk Fisik Rebana Gending}

Secara fisik instrumen rebana yang terdapat di dalam barungan gamelan Rebana Gending walaupun sama-sama disebut dengan rebana dan terdapat membrane dari kulit sebagai sumber bunyinya, namun memiliki perbedaan yang sangat signifikan dalam beberapa elemennya. Instrumen Rebana Gending mimiliki beberapa elemen yang tidak ditemui pada instrumen rebana pada umumnya. Secara organologis instrumen rebana terdiri dari beberapa bagian yaitu: pelawah (wadah) yang terbuat dari kayu nangka, pada bagian depan terdapat lapisan kulit sapi/kambing yang sebagai sumber bunyi, pada bagian samping terlihat ada tali kawat yang terbuat dari besi dan pada bagian 


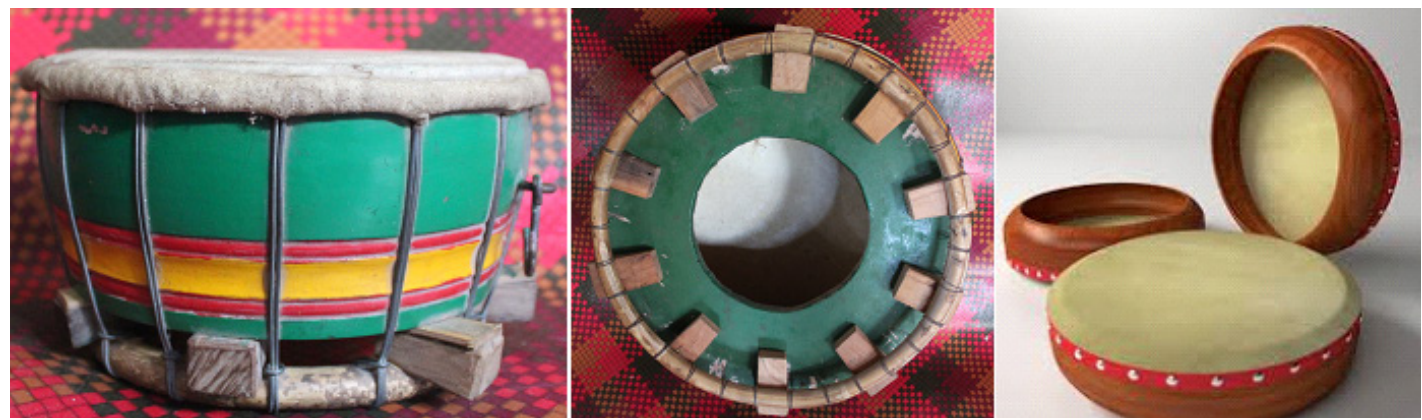

Gambar 2. Lobang resonator instrumen rebana gending (Dokumen: I Gede Yudarta, 2020)

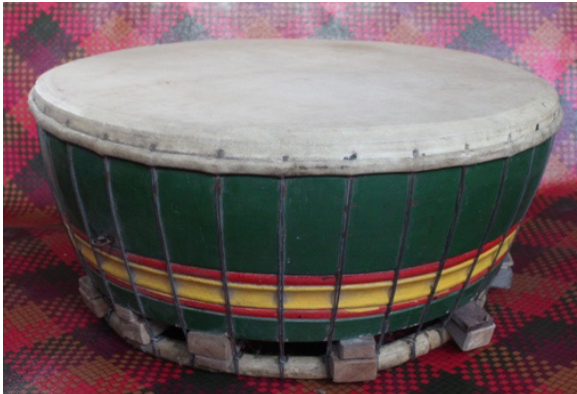

Gambar 3. Gong

(Dokumen, I Gede Yudarta'2020)

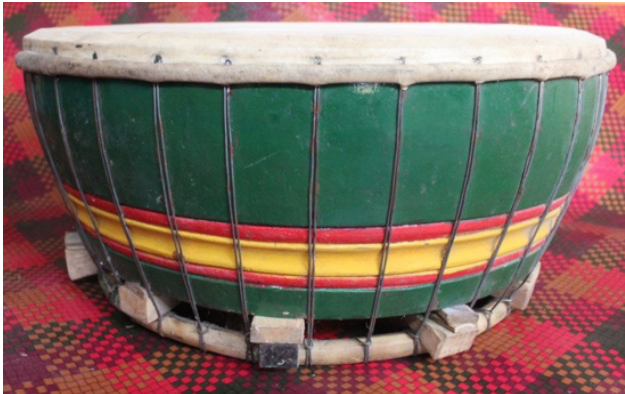

Gambar 4. Instrumen Kempul (Dokumen, I Gede Yudarta'2020) belakang terdapat rotan yang dibentuk melingkar yang berfungsi sebagai pengencang, pasak potongan kayu yang berfungsi sebagai pengatur suara serta lobang resonator (lihat gambar 1).

Adanya beberapa elemen sebagaimana digambarkan di atas, terdapat perbedaan yang signifikan dengan instrumen rebana biasa (lihat gambar 2).

Di dalam barungan instrumen Rebana Gending walaupun memiliki bentuk yang sama, terdapat berbagai nama jenis instrumen dengan ukuran yang berbeda-beda sesuai dengan fungsinya di dalam barungan. Adapun jenis-jenis instrumen yang tergabung di dalam ensambel Rebana Gending diantaranya:

\section{Gong}

Gong adalah instrumen rebana terbesar di dalam ensambel Rebana Gending. Instrumen ini memiliki ukuran diameter muka $64 \mathrm{~cm}$, diameter belakang $55 \mathrm{~cm}$, tinggi $28 \mathrm{~cm}$, lobang resonator $27,5 \mathrm{~cm}$ (lihat gambar 3).

\section{Kempul}

Instrumen kempul memiliki bentuk yang sama dengan gong namun perbedaannya terdapat pada ukuran diameter yang lebih kecil dan lebih tinggi dibandingkan dengan instrumen gong. Adapun ukuran dari instrumen kempul adalah: diameter muka $55 \mathrm{~cm}$, diameter belakang $47 \mathrm{~cm}$, tinggi $29 \mathrm{~cm}$, lobang resonator 22,5 $\mathrm{cm}$ (lihat gambar 4).

\section{Gendang}

Di dalam ensambel Rebana Gending terdapat dua jenis gendang, yaitu gendang jidur dan gendang gupekan. Kedua jenis gendang tersebut terdiri atas sepasang gendang wadon dan gendang lanang yang masing-masing memiliki fungsi yang berbeda menurut komposisi yang dimainkan. Sepasang gendang jidur digunakan untuk mengiringi komposisi pasasakan dan sekatian, sedangkan sepasang gendang gupekan digunakan untuk memainkan komposisi kakebyaran. Perbedaan lainnya terdapat pada teknik permainannya. Jika gendang jidur dimainkan oleh seorang pemain, gendang gupekan dimainkan oleh dua orang pemain.

\section{Gendang Jidur}

Gendang jidur memiliki bentuk seperti rebana, namun ukurannya lebih panjang dari instrumen rebana lainnya. Untuk gendang jidur wadon ukuran diameternya 33 $\mathrm{cm}$, tinggi $27 \mathrm{~cm}$, diameter bagian belakang $29 \mathrm{~cm}$ dan diameter resonator $14,5 \mathrm{~cm}$. Sedangkan gendang lanang memiliki ukuran diameter $30 \mathrm{~cm}$, tinggi $19 \mathrm{~cm}$, diameter bagian belakang $25,5 \mathrm{~cm}$ dan diameter resonator $15 \mathrm{~cm}$ (lihat gambar 5).

\section{Gendang Gupekan}

Sebagaimana gendang jidur, gendang gupekan juga terdiri dari sepasang yaitu gendang wadon dan gendang lanang. Gendang ini sangat mirip dengan kendang Bali dimana kedua sisinya kanan dan kiri dilapisi dengan kulit. Adapun ukuran gendang gupekan yang digunakan di dalam ensambel Rebana Gending adalah gendang wadon memiliki diameter 30 untuk bagian depan dan 28 untuk bagian belakang, panjang $72 \mathrm{~cm}$, dan gendang lanang memiliki ukuran diameter 29,5 cm untuk bagian depan dan 


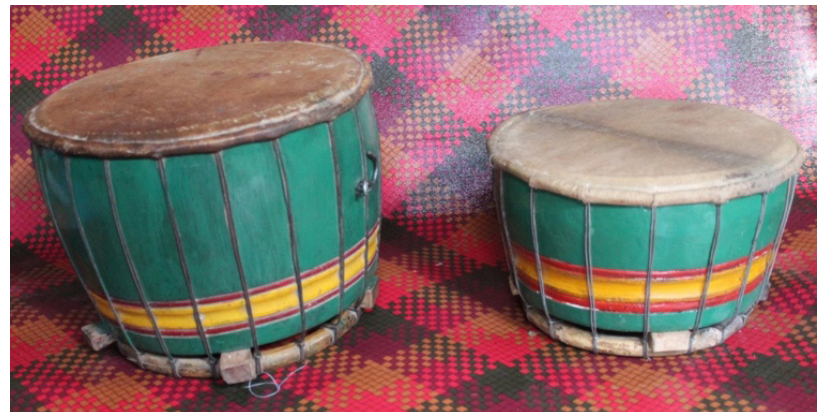

Gambar 5. Gendang Jidur Wadon dan Lanang (Dokumen, I Gede Yudarta'2020)

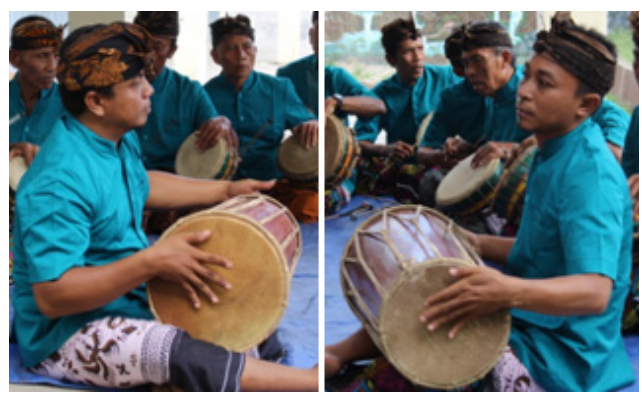

Gambar 6. Gendang Lanang dam Wadon

(Dokumen, I Gede Yudarta'2020)

$27 \mathrm{~cm}$ untuk bagian belakang serta panjang $71 \mathrm{~cm}$ (lihat gambar 6).

\section{Petuk}

Instrumen petuk di dalam ensambel rebana gending juga memiliki bentuk yang sama dengan rebana. Instrumen ini memiliki ukuran diameter atas $21 \mathrm{~cm}$, diameter bawah 9 $\mathrm{cm}$, tinggi $10 \mathrm{~cm}$ dan lobang resonator $10 \mathrm{~cm}$ (lihat gambar 7).

\section{Barangan}

Barangan adalah instrumen rebana yang memiliki nadanada pentatonis yang berlaras pelog pasasakan. Terdapat dua jenis barangan yaitu barangan besar dan barangan kecil. Kedua jenis barangan ini memiliki susunan nadanada yang terdiri dari nung, nang, ning, nong dan neng. Untuk nada tengah yaitu ning sering juga disebut dengan istilah penyelak.

Perbedaan diantara kedua jenis barangan ini terletak pada ukurannya. Untuk jelasnya dapat dicermati pada tabel berikut.

Tabel 1. Susunan Nada-Nada Instrumen Barangan

\begin{tabular}{lllllll}
\hline \multirow{2}{*}{ No } & Nama & Nada & & \multicolumn{2}{l}{ Ukuran $(\mathrm{Cm})$} & \\
\cline { 4 - 7 } & Instrumen & & $\begin{array}{l}\text { Diameter } \\
\text { atas }\end{array}$ & $\begin{array}{l}\text { Diameter } \\
\text { bawah }\end{array}$ & Tinggi & $\begin{array}{l}\text { Diameter } \\
\text { Resonator }\end{array}$ \\
\hline 1 & Terompong & Nung & 33 & 31 & 9,5 & 16 \\
\hline 2 & Pengempat & Nang & 31,5 & 29 & 10 & 15,5 \\
\hline 3 & $\begin{array}{l}\text { Pelimaq/ } \\
\text { Penyelaq }\end{array}$ & Ning & 28 & 25,5 & 10,5 & 14,5 \\
\hline
\end{tabular}

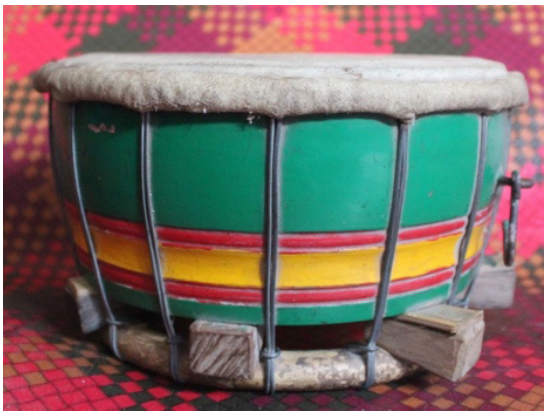

Gambar 7. Petuk

(Dokumen, I Gede Yudarta'2020)

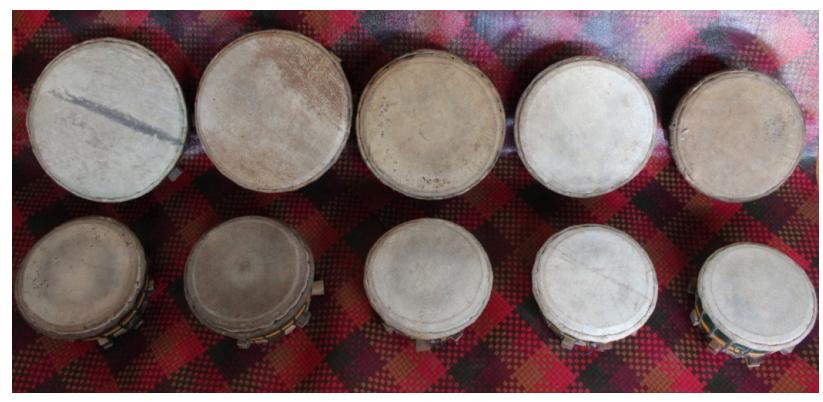

Gambar 8. Barangan

(Dokumen, I Gede Yudarta'2020)

\begin{tabular}{lllllll}
\hline 4 & Tongseh & Nong & 26,5 & 23 & 10 & 12,5 \\
\hline 5 & Pemaliq & Neng & 25 & 23 & 9 & 12,5 \\
\hline 6 & Terompong & Nung & 23 & 22 & 8,5 & 11.5 \\
\hline 7 & Pengempat & Nang & 22,5 & 21 & 10 & 12 \\
\hline 8 & $\begin{array}{l}\text { Pelimaq/ } \\
\text { Penyelaq }\end{array}$ & Ning & 22 & 21 & 8 & 10 \\
\hline 9 & Tongseh & Nong & 21 & 19 & 8,5 & 9,5 \\
\hline 10 & Pemaliq & Neng & 19 & 17 & 8 & 9,5 \\
\hline
\end{tabular}

\section{Rincik}

Rincik merupakan instrumen non-membran yang terdapat di dalam barungan Rebana Gending. Instrumen ini terbuat dari kerawang berbentuk cymbal. Di dalam sebuah rincik terdapat 8 (delapan) buah cymbal kecil 6 (enam) buah yang diletakkan di atas sebidang pelawah kayu dan 2 (dua) buah cymbal digunakan sebagai pemukul. Instrumen ini juga tergolong idiophone karena dimainkan dengan cara dipukul dibenturkan dengan dua buah cymbal kecil.

\section{Suling}

Selain rincik, instrumen non-membran yang juga terdapat di dalam barungan Rebana Gending adalah instrumen suling. Instrumen ini merupakan instrumen aerophone yang dimainkan dengan cara ditiup.

\section{Wujud Musik Rebana Gending}

Wujud musik secara umum dapat dibagi menjadi dua yaitu musik instrumental dan musik pengiring. Musik instrumental adalah musik yang dimainkan hanya bersumber dari suara instrumen, sedangkan 


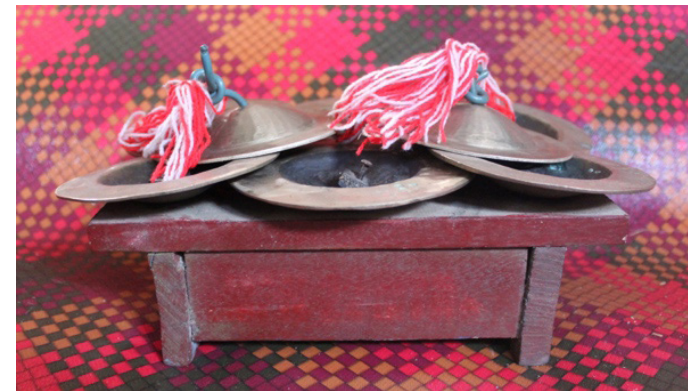

Gambar 9. Rincik

(Dokumen, I Gede Yudarta'2020)

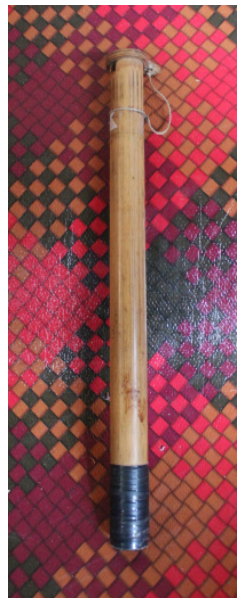

Gambar 9. Suling

(Dokumen, I Gede Yudarta'2020)

musik pengiring adalah musik yang secara sengaja diciptakan untuk mengiringi berbagai bentuk seni seperti tari, vokal, drama, dan berbagai aktivitas budaya lainnya. Sebagai salah satu kesenian tradisional, wujud musik Rebana Gending mencakup kedua wujud sebagaimana diuraikan di atas yaitu sebagai musik instrumental dan musik pengiring. Sebagai musik instrumental kesenian Rebana Gending hanya memainkan musik dari berbagai instrumen yang terdapat di dalamnya. Sedankan sebagai musik pengiring, Rebana Gending dikaitkan dengan berbagai aktivitas seni seperti tari, vocal, drama serta mengiringi nyongkolan dan besunat yang merupakan aktivitas budaya masyarakat Sasak.

Dari kedua wujud musik tersebut, musik Rebana Gending memiliki bentuk dan struktur yang beragam. Secara umum bentuk dan struktur komposisi musik tradisional Sasak memiliki kesamaan dan dapat dimainkan dengan ensambel yang berbeda.

\section{Bentuk Gending}

Bentuk di dalam sebuah musik adalah merupakan kerangka dasar dari musik itu sendiri. Sebagaimana umumnya musik tradisional Sasak, Rebana Gending memiliki bentuk musik yang sederhana. Kerangka dasar musik tradisional Sasak ada yang berbentuk tunggal, ganda dan jamak. Bentuk tunggal dan ganda biasanya terdapat pada musik yang dimainkan dalam mengiringi prosesi adat, sedangkan bentuk yang jamak biasanya digunakan di dalam musik iringan tari dan iringan wayang.

Rebana Gending adalah ensambel musik yang umumnya digunakan dalam pelaksanaan prosesi atau pawai adat Sasak. Dari penggunaannya tersebut dapat dipastikan bahwa bentuk musik yang dimainkan di dalam gamelan Rebana Gending adalah tunggal dan ganda. Bentuk tunggal adalah komposisi gending pasasakan yang di dalam komposisinya hanya terdapat satu rangkaian melodi yang dimainkan dari awal hingga selesai. Beberapa komposisi yang tergolong berbentuk tunggal diantaranya komposisi gending sekatian seperti gending Cepung, gending Ciloleng dan beberapa jenis gending sekatian lainnya.

Sedangkan bentuk ganda yang terdapat pada komposisi gending Rebana adalah adanya perbedaan di antara bagianbagian yang dimainkan dalam di dalam lagu tersebut. Sebagaimana gending Petegelan Ate bagian penembiq diambil dari potongan bagian pagending. Sedangkan untuk bagian penutuq diisi dengan gilak. Musik Rebana Gending yang berbentuk jamak dapat dicermati pada beberapa komposisi yang biasanya digunakan sebagai musik iringan tari dan drama Cupak Gerantang. Bentuk musiknya mengacu kepada tarian yang diiringi dan setiap adegan yang terdapat di dalam drama Cupak Gerantang. Beberapa gending kakebyaran yang sangat populer dimainkan dengan Rebana Gending juga tergolong musik dalam bentuk jamak.

Dari berbagai bentuk musik tersebut, jika diklasifikasikan menurut jenisnya, maka secara umum dapat dibagi menjadi tiga yaitu, pasasakan, sekatian dan kakebyaran.

\section{Pasasakan}

Sebagaimana umumnya musik pasasakan, penyajiannya merupakan kombinasi atau perpaduan antara musik vokal dan instrumental. Adapun vokal yang disajikan berupa puji-pujian kepada alam, penguasa serta mengisahkan kehidupan orang-orang Sasak. Beberapa musik pasasakan yang populer di kalangan masyarakat seperti Gending Prabu, Tagelan Ate, Pemban Seleparang, Gelung Prada, Gugur Mayang, Kidung Dalem, Mas Mirah merupakan gending-gending yang mengangkat kehidupan manusia. Gending-gending pasasakan yang dimainkan di dalam ensambel Rebana Gending dikembangkan oleh I Komang Kantun ketika bertugas di Taman Budaya. Dikembangkannya gending pasasakan pada Rebana Gending tujuannya adalah untuk mengisi kegiatan yang dilaksanakan di lingkungan Taman Budaya Mataram.

\section{Sekatian (Pengalang Ate)}

Komposisi atau gending sekatian merupakan salah satu bentuk komposisi musik tradisional Sasak yang iramanya lebih cepat. Menurut I Komang Kantun, salah seorang tokoh dalam seni tradisional Sasak, mengatakan bahwa gending-gending sekatian ini diadopsi dari gending 


\begin{tabular}{|c|c|c|c|c|c|c|c|c|c|c|c|c|c|c|}
\hline - & - & - & $\mathrm{e}$ & - & $\mathrm{e}$ & 0 & e & - & $\mathrm{i}$ & 0 & e & u & $\mathrm{e}$ & 0 \\
\hline - & - & $\overline{10}$ & e & u & $\mathrm{e}$ & 0 & e & - & 1 & 0 & e & u & $\mathrm{e}$ & 0 \\
\hline - & - & $\overline{\mathrm{oe}}$ & $\mathrm{u}$ & $\mathrm{a}$ & U & e & u & - & 0 & e & u & $\mathrm{a}$ & u & e \\
\hline - & - & $\overline{\mathrm{oe}}$ & u & $a$ & $\mathrm{u}$ & e & u & - & 0 & $\mathrm{e}$ & u & $\mathrm{a}$ & $\mathrm{u}$ & e \\
\hline - & - & $\overrightarrow{\mathrm{oe}}$ & u & 0 & $\mathrm{e}$ & $\mathrm{u}$ & $a$ & - & $\mathrm{u}$ & $\overline{\mathrm{eo}}$ & $\mathrm{e}$ & $\mathrm{u}$ & $a$ & $\mathrm{e}$ \\
\hline - & - & eo & $\mathrm{e}$ & u & $\mathrm{a}$ & 1 & $a$ & - & $\mathrm{e}$ & $\mathrm{u}$ & $\mathrm{a}$ & 1 & a & $\mathrm{u}$ \\
\hline - & - & 0 & i & 0 & 1 & $\mathrm{a}$ & u & a & 1 & $\mathrm{a}$ & i & 0 & $\mathrm{e}$ & 0 \\
\hline
\end{tabular}

Gambar 12. Notasi Gending Cepung

pangecet yang terdapat pada komposisi karawitan Bali (wawancara tanggal 31 Juli 2020 via telpon). Gending sekatian ini berasal dari daerah Bali Utara dan sudah ada di Lombok sejak pertama kali munculnya gamelan Gong Kebyar tahun 1923. Gending sekatian selain dimainkan di dalam gamelan Gong Kebyar juga dapat dimainkan dengan menggunakan ensambel Rebana Gending dan berbagai jenis ensambel musik tradisional Sasak lainnya.

\section{Kakebyaran}

Gending kakebyaran merupakan salah satu materi yang sering dimainkan dengan ensambel Rebana Gending. Komposisi ini seutuhnya diambil dari komposisi kakebyaran yang berasal Bali. Semaraknya perkembangan seni kakebyaran di Lombok turut mempengaruhi perkembangan musik tradisional Sasak. Beberapa repertoar kakebyaran yang cukup popular di kalangan seniman seperti gending pengiring tari Oleg, Kebyar Duduk, Manukrawa, Panji Semirang, Wiranata dan yang lainnya sangat lumrah dimainkan dengan Rebana Gending. Penyajian musik kakebyaran bagi anggota sekehe merupakan sesuatu yang sangat membanggakan. Sebagaimana dikatakan Amaq Saturi, lebih enak memainkan musik kebyar dibandingkan dengan sekatian dan memainkan musik kebyar adalah kebanggaan bagi sekehe Rebana Gending (wawancara tanggal 23 Juli 2020). Pernyataan ini sangat mirip seperti apa yang dikatakan oleh para seniman Sasak dimana mereka sangat bangga ketika mampu memainkan gending-gending kakebyaran dalam berbagai bentuknya seperti tabuh kreasi baru, lelambatan, iringan tari. Bahkan muncul ungkapan di kalangan seniman, "jangan merasa bangga sebagai seniman sebelum mampu memainkan gending kakebyaran dengan gamelan Gong Kebyar". Fenomena dan ungkapan inilah yang akhirnya memacu para seniman Sasak untuk mempelajari seni kakebyaran secara lebih mendalam. Tidak saja memainkan gending kakebyaran, bahkan banyak diantaranya yang membeli gamelan Gong Kebyar. Bagi para seniman Rebana Gending di Desa Langko, gending-gending kakebyaran yang mereka mainkan seolah-olah menjadi salah satu ciri khas mereka. Mereka sangat senang dan bangga dapat memainkan beberapa repertoar seni kakebyaran.

\section{Struktur Gending}

Selain komposisi kakebyaran yang sudah memiliki struktur sebagaimana dari daerah asalnya (Bali), komposisi musik tradisional Sasak memiliki struktur yang sangat sederhana. Kesederhanaan komposisi musik tradisional Sasak sangat terkait dengan konsep estetik/keindahan dan nilai-nilai kehidupan yang dianut oleh masyarakat Sasak. Di dalam nilai estetika masyaraat Sasak terdapat konsep semaiq dan paut yang memiliki makna kesederhanaan dan kepantasan. Kesederhanaan atau semaiq bukanlah menunjukkan sesuatu yang tidak tuntas, akan tetapi memiliki makna kecukupan dan tidak terlalu berlebihan. Sedangkan paut atau kepantasan memiliki makna kejujuran dan tidak bertentangan dengan norma kesusilaan.

Komposisi musik tradisional Sasak secara umum memiliki struktur yang sederhana terdiri dari bagian-bagian yang membentuk satu kesatuan komposisi. Terdapat dua pola struktur yaitu gending yang berstruktur sederhana dan gending yang berpola struktur lengkap. Pola struktur sederhana adalah komposisi gending pasasakan yang di dalam komposisinya hanya terdapat bagian penembiq dan pegending dengan menggunakan satu rangkaian melodi yang digunakan sebagai bagian penembiq (pembuka), dan pagending (bagian tubuh lagu). Beberapa komposisi yang memiliki pola struktur sederhana biasanya terdapat pada komposisi gending sekatian seperti gending Cepung, gending Ciloleng dan beberapa jenis gending sekatian lainnya. Sedangkan komposisi yang berpola struktur lengkap adalah komposisi yang memiliki beberapa rangkaian melodi yang berbeda dari bagian penembiq, pagending, dan panutuq. Beberapa komposisi yang memiliki pola struktur jamak biasanya terdapat pada komposisi gending pasasakan seperti gending Prabu, Pemban Seleparang, Gelung Prada dan berbagai jenis gending pasasakan lainnya.

\section{Fungsi Kesenian Rebana Gending}

Secara konstekstual musik memiliki fungsi yang sangat universal dalam berbagai aspek kehidupan manusia. Sebagaimana umumnya seni itu diciptakan, musik juga memiliki tujuan untuk bermain-main mengisi waktu luang 
(theory of play), seluruh aktivitas artistiknya bertujuan untuk kepentingan praktis dan kebutuhan sosial (theory of utility) (dalam Pramono, 2008:54-55). Di sisi yang lain mengutip pernyataan Koentjaraningrat (dalam Sudirga, 2004:125), aktivitas budaya musik memiliki keterkaitan yang sangat erat dengan tradisi dan budaya masyarakat dimana musik tersebut diciptakan. Tujuannya adalah untuk memuaskan suatu rangkaian dari sejumlah kebutuhan naluri manusia yang berkaitan dengan kehidupannya. Lebih spesifik Alan P. Merriam menyebutkan bahwa dalam pandangan ethnomusikolog suatu budaya musik harus ditempatkan pada masyarakat itu sendiri, tidak hanya meliputi analisis struktural suara musik, melainkan mencakup pula gagasan-gagasannya, tindakannya, karena musik adalah suatu gejala manusia, untuk manusia dan mempunyai fungsi dalam situasi sosial (dalam Sudirga, 2004:126). Dari pandangan ini dapat dicermati bahwa musik sebagai hasil kreativitas dan aktivitas budaya memiliki keterkaitan dan fungsi yang sangat penting bagi kehidupan sosial di masyarakat.

Keberadaan kesenian Rebana Gending di dalam kehidupan masyarakat Sasak memiliki fungsi yang sangat beragam. Selain berfungsi sebagai media untuk memenuhi naluri estetik, juga sebagai sarana penunjang berbagai aktivitas budaya dan kehidupan sosial. Masyarakat adat Sasak memiliki berbagai bentuk ragam budaya yang sudah tertanam sebagai warisan yang hingga saat ini masih eksis dilaksanakan. Berbagai ragam budaya tersebut terangkum tradisi adat gama, adat luir gama dan tapsila serta tradisi yang berkaitan dengan kehidupan manusia yaitu gawe urip dan gawe pati (Yudarta, 2015:372). Sehubungan dengan tradisi ini kesenian Rebana Gending dapat difungsikan dalam tradisi adat luir gama dan ketika dilaksanakan gawe urip. Adat luir gama adalah upacara yang diselenggarakan sehubungan dengan terjadinya kemarau panjang atau hujan yang turun secara berlebihan. Sedangkan gawe urip merupakan rangkaian tradisi dari awal keberadaan manusia di dalam kandungan hingga mencapai kehidupan berumah tangga (Syam, 2008:59). Dalam konteks tradisi tersebut, kesenian Rabana Gending biasanya digunakan untuk mengiringi prosesi adat khitanan dan nyongkolan yang merupakan bagian tradisi gawe urip yang hingga saat ini sering dilaksanakan di kalangan masyarakat Sasak.

Berkaitan dengan kehidupan sosial, keberadaan kesenian Rebana Gending yang terdapat di Desa Langko berfungsi untuk mempererat hubungan sosial antara anggota sekehe dengan masyarakat, antara sesama anggota sekehe dan dengan sekehe-sekehe yang lainnya. Bagi masyarakat di Desa Langko, kesenian ini memiliki arti yang penting dan sangat membantu ketika melaksanakan upacara adat. Mereka yang melaksanakan roah (upacara) tidak perlu lagi mengeluarkan biaya yang mahal untuk menyewa kesenian dari luar. Selain untuk membantu mayarakat di sekitar Desa Langko, sekehe ini juga sering ditanggap oleh masyarakat yang ada di luar desa tersebut untuk mengiringi prosesi dan upacara adat. Bagi kalangan anggota sekehe, keberadaan sekehe Buana Putra dapat mempererat hubungan sosial dan kekerabatan diantara mereka. Hubungan tersebut tidak saja sebatas aktivitas berkesenian, namun juga dalam kegiatan-kegiatan sosial lainnya. Kerja sama dan gotong royong ketika salah satu anggota sekehe memiliki kegiatan selalu dilaksanakan dengan penuh rasa kekeluargaan. Hubungan sosial dalam skala yang lebih luas juga terjalin antara sekehe Buana Putra dengan sekehe-sekehe yang lainnya. Saling dukung diantara sekehe tersebut terjadi ketika pada salah satu sekehe kekurangan anggota dan dibantu oleh anggota sekehe yang lain. Terjalin hubungan sosial sebagaimana diuraikan di atas menunjukkan bahwa keberadaan kesenian Rebana Gending dapat digunakan sebagai media komunikasi yang efektif sehingga nantinya dapat diwujudkan harmoni di dalam kehidupan masyarakat yang lebih luas.

Selain kedua fungsi di atas, kesenian Rebana Gending di Desa Langko juga memiliki fungsi ekonomi dimana dari berbagai event yang mereka lakukan di berbagai tempat atas undangan masyarakat, pemerintah dan para steakholder di dunia pariwisata ada penghasilan yang dapat digunakan untuk menunjang aspek ekonomi para anggota sekehe. Dari ongkos pagelaran yang diperoleh berkisar antara 3-4 juta rupiah mereka kumpulkan untuk nantinya dapat dibagikan secara merata untuk hari raya, biaya perawatan peralatan, dan untuk pengadaan kostum penabuh.

Dari ke tiga fungsi di atas hal ini menunjukkan bahwa kesenian Rebana Gending memiliki eksistensi yang baik di kalangan masyarakat, tidak saja dimanfaatkan oleh masyarakat setempat namun juga oleh pihak-pihak lain seperti pemerintah, dan swasta khususnya hotel yang ada di beberapa kawasan wisata. Namun akibat dari bencana nasional Covid-19, semua aktivitas tersebut akhirnya tertunda dan beberapa diantaranya batal untuk dilaksanakan. Hal ini tentunya berdampak negative terhadap keberadaan kesenian termasuk diantaranya kesenian Rebana Gending.

\section{SIMPULAN}

Menyimak fenomena sebagaimana diuraikan dalam artikel ini dapat disimpulkan bahwa di dalam masa pandemic Covid-19, berbagai bentuk aktivitas budaya termasuk diantaranya kesenian Rebana Gending terdampak secara signifikan sebagai akibat adanya himbauan dan larangan dari pihak pemerintah untuk melaksanakan kegiatan yang bersifat massal atau melibatkan banyak orang.

Kesenian Rebana Gending sebagai salah satu hasil kreativitas masyarakat Sasak di bidang seni merupakan kesenian yang sarat dengan nilai-nilai tradisi dan budaya Sasak. Kesenian ini memiliki bentuk yang sangat unik berbeda dengan bentuk kesenian rebana pada umumnya. 
Perbedaannya terletak pada bentuk, dan fungsi dalam kehidupan masyarakat Sasak. Bentuk kesenian Rebana Gending dapat dicermati pada bentuk fisik, komposisi gending yang terdapat di dalamnya. Secara organologis ensambel Rebana Gending didominir oleh instrumen yang tergolong membranophone dan dua buah instrumen nonmembrane yaitu rincik dan suling, Komposisi Rebana Gending terdiri dari tiga jenis yaitu pasasakan, sekatian dan kakebyaran yang masing-masing memiliki struktur yang terdiri dari struktur sederhana yang terdiri dari penembiq dan pegending dan struktur lengkap yang terdiri dari penembiq, pegending dan penutuq. Berkenaan dengan fungsinya, kesenian Rebana Gending memiliki beberapa fungsi yaitu penerapan nilai-nilai budaya, fungsi sosial dan fungsi ekonomi. Nilai-nilai budaya yang terdapat di dalam kesenian rebana gending diantaranya nilai kesederhanaan (semaiq), nilai kepatutam (paut), kerja sama, gotong royong dan digunakan dalam berbagai aktivitas budaya yaitu dalam tradisi adat luir gama dan gawe urip. Di bidang sosial keberadaan kesenian Rebana Gending adalah sebagai media komunikasi dan mempererat hubungan antara seniman dengan masyarakat, antara seniman dengan seniman serta mempererat hubungan antar kelompok atau sekehe yang berkecimpung di dalam seni Rebana Gending. Secara ekonomis, kesenian Rebana Gending cukup berperan di dalam menambah penghasilan para seniman dan untuk biaya perawatan dan pemeliharaan kesenian yang dimiliki.

\section{DAFTAR RUJUKAN}

Anwar, Dessy. (2001). Kamus Lengkap Bahasa Indonesia. Surabaya: Karya Abdi Tama

Poerwadarminta, W.J.S. (2007). Kamus Umum Bahasa Indonesia (Edisi Ketiga). Jakarta: Balai Pustaka

Pramono, Kartini. (2008). Horizon Estetika. Yogyakarta: Badan Penerbitan Filsafat UGM

Sudirga, I Komang. (2005). Cekepung Ensambel Vokal Bali. Yogyakarta: Kalika Press.

Syam, H. Nur. 2008. Islam Lokal: Akulturasi Islam Di Bumi Sasak. Lombok Tengah: STAIIQH Press.

Yaningsih, Sri. (1991/1992). Ensiklopedi Musik Dan Tari daerah Nusa Tenggara Barat. Departemen Pendidikan dan Kebudayaan, Kantor Wilayah Propinsi Nusa Tenggara Barat. Proyek Pembinaan Kesenian NTB

Yudarta, I Gede dan I Nyoman Pasek. (2015). "Revitalisasi Musik Tradisional Prosesi Adat Sasak Sebagai Identitas Budaya Masyarakat Sasak". Penelitian Hibah Bersaing. Institut Seni Indonesia Denpasar.
Yudarta, I Gede. (2015). "Revitalisasi Musik Tradisional Prosesi Adat Sasak Sebagai Identitas Budaya Sasak", Jurnal Segara Widya Vol.3 No 1. UPT. Penerbitan Institut Seni Indonesia Denpasar

Yudarta, I Gede. (2016). "Revitalisasi Musik Tradisional Prosesi Adat Sasak Sebagai Identitas Budaya Sasak", Hasil Penelitian Hibah Bersaing. Dengan DIPA Direktorat Riset dan Pengabdian Masyarakat No DIPA 042.060/2016, tanggal 7 Desember 2015. Institut Seni Indonesia Denpasar

https://www.kbbi.web.id/eksistensi https://www.kompas.com/covid-19 